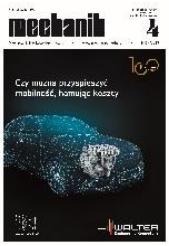

How to cite this article:

Authors: Ewa Kasprzycka, Arkadiusz Więczkowski, Bogdan Bogdański

Title of article: „Increased durability of selected tools used in the rubber industry by hybrid treatment”

Mechanik, No. 4 (2019)

DOI: https://doi.org/10.17814/mechanik.2019.4.34

\title{
Increased durability of selected tools used in the rubber industry by hybrid treatment
}

\author{
EWA KASPRZYCKA \\ ARKADIUSZ WIĘCZKOWSKI \\ BOGDAN BOGDAŃSKI *
}

Dr hab. Ewa Kasprzycka (ewa.kasprzycka@pw.edu.pl), https://orcid.org/0000-0002-9856-2831 - Wydział Budownictwa, Mechaniki i Petrochemii, Politechnika Warszawska, Warszawa, Polska

Dr inż. Arkadiusz Więczkowski (arkadiusz.wieczkowski@michelin.com), https://orcid.org/0000-0001-5401-0093 - Michelin Polska SA Dr inż. Bogdan Bogdański (bogdan@imp.edu.pl), https://orcid.org/0000-0002-6719-2380 - Instytut Mechaniki Precyzyjnej, Warszawa, Polska

This research concerns hybrid layers of the $\mathrm{CrC}+\mathrm{CrN}$ type, produced on the tool steel surface in subsequent processes, diffusion chromizing, carried out by inexpensive and technologically simple powder method, combined with the next arc evaporation treatment Arc PVD (arc evaporation physical vapour deposition), made for the deposition of chromium nitride coatings. Investigations of the microstructure of hybrid layers, as well as of their phase composition and concentration depth profiles of elements in diffusion zone of these layers, were carried out. In addition, the layers hardness, their tribological properties (pin-on-disk method) and corrosion resistance have been determined. It has been shown that hybrid layers of the $\mathrm{CrC}+\mathrm{CrN}$ type are characterized by very good tribological properties at ambient temperature $25^{\circ} \mathrm{C}$ and at temperature $100^{\circ} \mathrm{C}$ as well as by very good resistance to corrosion in a solution containing chlorine ions.

KEYWORDS: diffusion chromizing, Arc PVD treatment, hybrid layer, tribological properties, corrosion

\section{Introduction}

The subject of the research was to assess the possibilities of increasing the durability of tools used in the rubber industry due to the use of modern surface engineering techniques. In this industry, e.g. in the production of tires, durability of tools intended for working with rubber is of decisive importance in ensuring the required quality of products and in striving to reduce production costs.

Cutting tools, e.g. disc-cutters generally made of alloy steel, are exposed to the rubber compound or - at a later stage - to the rubber. During production, the rubber mixture is heated, its temperature must not exceed 100 ${ }^{\circ} \mathrm{C}$. The rubber mix has a steel or textile cord, which has a significant impact on the deterioration of tribological properties of the disc cutters during cutting and their rapid wear, which causes costly production downtime associated with the replacement of the disc-cutters.

Figs. 1 and 2 show a disc-cutter for cutting rubber as well as its cutting edge and blade shape. In most cases, destruction of materials in operational processes is focused on the surface layer. Therefore, tests were carried out on the working surface of the disc-cutter after half a year of its operation to determine the factors that destroy it when cutting rubber $[1,2]$. Pictures of the working surface of the disc-cutter, taken with a digital microscope (Keyence VHX 1000) revealed the presence of a grid of scratches characteristic of the mechanism of abrasive wear by furrowing (fig. 3).

When cutting the rubber on the working surface of the knife, scratches are formed, which worsen its quality, and finally lead to the tool being out of service. Based on the test results, it can be assumed that the main destructive factor in this case is abrasive wear by furrowin. 


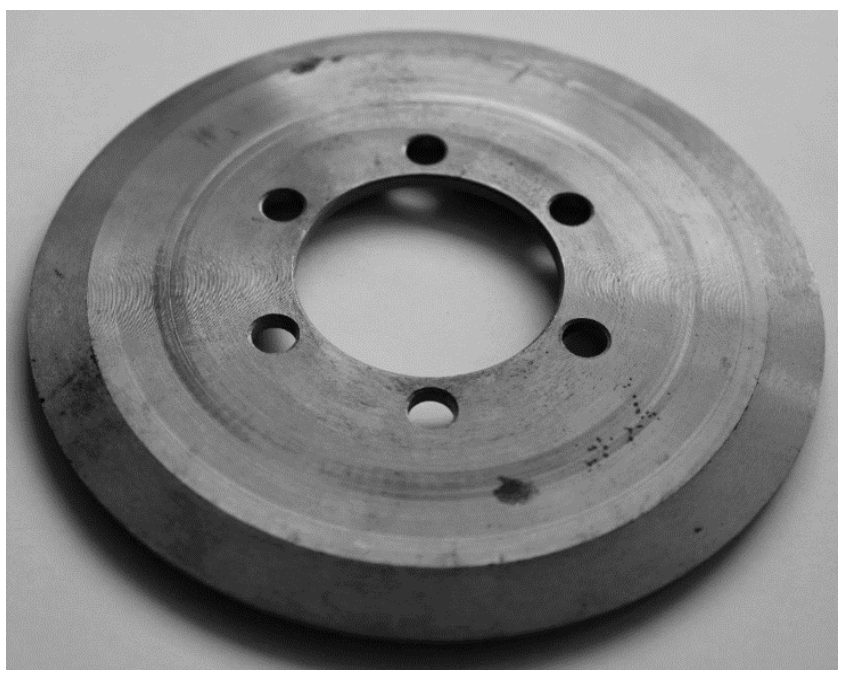

Fig. 1. Disc-cutter for cutting rubber after six months of use

a)

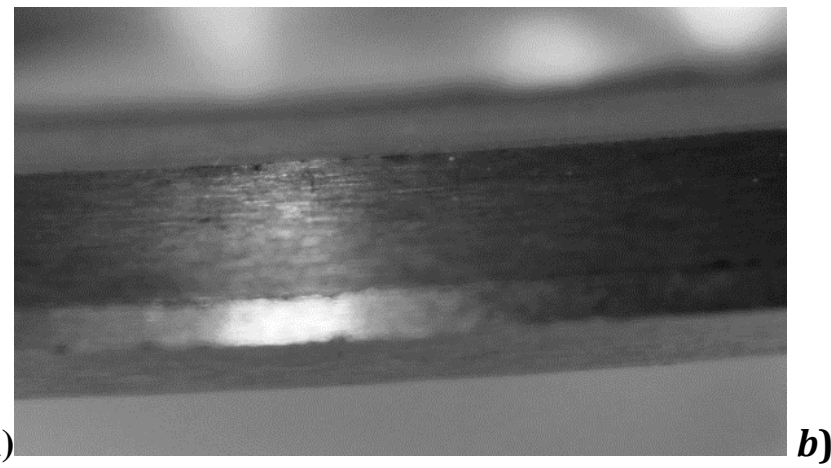

Fig. 2. Disc-cutter for cutting rubber: a) cutting edge, b) blade shape with so-called blunt trapezoidal blade

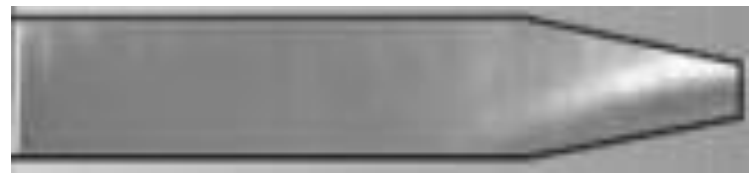

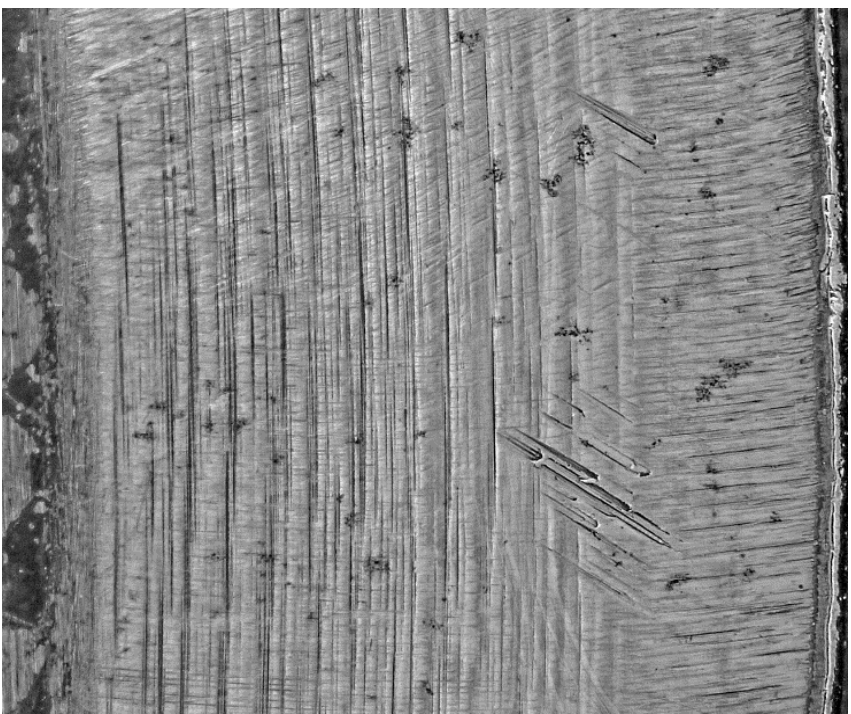

Fig. 3. Working surface of a disc-cutter for cutting rubber after six months of operation with visible scratches (photo taken with a Keyence VHX 1000 digital microscope)

The second factor that destroys disc-cutters during operation is the increased temperature, caused - as mentioned - by heating the rubber compound during processing (to a temperature below $100{ }^{\circ} \mathrm{C}$ ). The third destructive factor is corrosion, which occurs as a result of spraying disc-cutters with cold water to remove excess heat generated during cutting.

In the light of the literature, the chance to improve the properties of steel tools exposed to several destructive factors occurring during their operation (such as tribological wear, high temperature and corrosion) is given by the use of modern surface engineering techniques, including hybrid technologies [3-5].

Hybrid technologies consist in carrying out several different surface treatments in order to produce a surface layer with usable properties unattainable by using one surface machining technology [4]. 
The best effects - according to literature data [4-6] - produce hybrid layers in thermo-chemical machining processes, e.g. diffusion nitriding or chromizing, combined with Arc PVD (arc evaporation physical vapor deposition) machining, performed in order to deposit chromium nitride coatings. Combination of two processes brings a synergy effect in the form of a hybrid layer with excellent performance properties, much better than can be obtained as a result of one process.

The research carried out in this work concerned hybrid layers of the $\mathrm{CrC}+\mathrm{CrN}$ type, produced on the surface of tool steel in subsequent diffusion chromizing processes, which were then combined with Arc PVD machining performed in order to deposit chromium nitride coatings.

Diffusion chromizing is used, among others, to increase the wear resistance of steel products due to friction and corrosion [7-9]. Industrial significance today is cheap and technologically simple method of powder diffusion chromizing (pack cementation powder method). It involves heating steel in a powder mixture containing ferro-chromium, which is a source of chromium atoms, an activator (e.g. ammonium chloride) enabling the transport of chromium atoms to the surface of chromium-plated steel and a ceramic filler (e.g. kaolin) preventing sintering of the powder at high temperature [7, 9-11].

The electric arc evaporation method - Arc PVD - allows for deposition of gas phase coatings under vacuum conditions, using physicochemical gas and plasma processes [3-5, 12-15]. Unlike crystallization processes occurring in the atmosphere of non-ionized gases $[16,17]$, during crystallization in the plasma environment, ions can be controlled by an external electric or magnetic field [3-5]. As a result, the deposited coating has much higher density and better adhesion to the substrate than coatings deposited in a non-ionized gas environment. Carbide layers ( $\mathrm{CrC}$ type), produced in the process of diffusion chromizing, are hard and wear resistant against friction [7-10, 18, 19]. Good performance properties, among others tribological and anticorrosive, are also shown by chromium nitride (CrN) coatings deposited by Arc PVD arc method [3-6, 13-15]. It should be emphasized that both types of layers/coatings are resistant to elevated temperature [4-7]. $\mathrm{CrN}$ coatings are characterized by very good adhesion to the surface of the chromium carbide layer [20].

The aim of the research was to modify the structure of chromium carbide layers by combining the diffusion chromizing process with the subsequent machining - Arc PVD - to produce hybrid layers of CrC+CrN type, resistant to three factors: abrasive wear, corrosion and elevated temperature. Production of hybrid layers with excellent performance properties will increase the durability and reliability of tools.

\section{Layer production}

Chromized carbide layers were produced on the surface of X210Cr12 alloy tool steel (containing: 1.90\% C, $12 \% \mathrm{Cr}$ ), often used to make knives for the rubber industry [2].

The powder diffusion chromizing method is described in detail in many publications [7-9, 19]. Diffusion chromizing processes were carried out in an electric furnace equipped with devices for temperature control and regulation.

Samples to be tested were placed in a powder mixture containing: $60 \%$ ferro-chromium powder, $39 \%$ kaolin, $1 \%$ ammonium chloride $\left(\mathrm{NH}_{4} \mathrm{Cl}\right)$, in boxes of special construction with lids, made of heat-resistant steel. The uniqueness of the boxes was their hermetic sealing during the process with enamel, which melts at temperatures above $600{ }^{\circ} \mathrm{C}$; which prevented from the oxidation of the charge. Filled boxes were placed in an oven chamber and baked. Diffusion chromizing processes were carried out at a temperature from 900 to 950 ${ }^{\circ} \mathrm{C}$, for 1 to 10 hours. After chromizing, heat curing was performed as needed (quenching at $990{ }^{\circ} \mathrm{C}$ for $30 \mathrm{~min}$ and tempering at $200{ }^{\circ} \mathrm{C}$ for 2 hours).

Machining of tool steel samples - necessary to produce hybrid layers of $\mathrm{CrC}+\mathrm{CrN}$ type - was divided into two stages, carried out on two different devices. First, diffusion chromizing of tool steel was carried out at the Institute of Precision Mechanics in Warsaw to produce a $\mathrm{CrC}$ type carbide layer on its surface. At the second stage, in order to produce hybrid layers of the $\mathrm{CrC}+\mathrm{CrN}$ type, chromium nitride $(\mathrm{CrN})$ was deposited on the surface of chromized steel. Coatings were deposited by Arc PVD electric arc evaporation method, using a Standard type device at the Institute of Sustainable Technologies - National Research Institute in Radom. Parameters of chromium nitride coating deposition by Arc PVD method are given in tab. I. 
TABLE I. Parameters of chromium nitride deposition processes by Arc PVD method

\begin{tabular}{|l|c|c|c|c|c|}
\hline \multicolumn{1}{|c|}{ Process type } & $\begin{array}{c}\text { Substrate temperature } \\
{\left[{ }^{\circ} \mathrm{C}\right]}\end{array}$ & $\begin{array}{c}\text { Polarization } \\
\text { voltage } U_{\text {BIAS }}[\mathrm{V}]\end{array}$ & $\begin{array}{c}\text { Pressure } \\
p[\mathrm{~Pa}]\end{array}$ & $\begin{array}{c}\text { Time } \\
{[\mathrm{min}]}\end{array}$ & Atmosphere \\
\hline Heating & 300 & - & $<1 \cdot 10^{-3}$ & 30 & - \\
\hline Etching with argon jons & 300 & -300 & $5.0 \cdot 10^{-1}$ & 25 & $\mathrm{Ar}$ \\
\hline Chromium ion etching & 400 & -300 & $5.0 \cdot 10^{-1}$ & 15 & $\mathrm{Ar}$ \\
\hline Deposition CrN & 380 & -150 & 3.5 & 120 & $\mathrm{Ar}+\mathrm{N}_{2}$ \\
\hline
\end{tabular}

\section{Layer testing methods}

Layer structure testing included: their microstructure and phase composition, elemental concentration distributions, and measurements of layer thickness and hardness. Layer microstructure tests were conducted on polished and etched transverse specimens of metallographic samples using an Nikon optical microscope type LV150. The phase composition of layers was determined by X-ray phase analysis using a diffractometer; $\mathrm{CuK \alpha}$ radiation was used. Linear analysis of the concentration of elements in the layers was carried out with a Cameca X-ray analyzer from WDS. Observations of the working surface of disc-cutters after their operation and surface of samples after tribological tests were carried out using a Keyence VHX 1000 digital microscope. Hardness of the layers was tested with a Nano-Hardness Tester equipped with a Berkovich indenter, with a 65 pyramid. In the case of testing the hardness of thin layers, this device allows for the condition that the indentation of the indenter does not exceed $10 \%$ of the thickness of the tested layer, which allows to eliminate the influence of the substrate on the measurement results.

Tribological properties (abrasive wear) of the layers were determined using the ball-on-disc method on a DUCOM tribotester. During the test, the $\mathrm{Al}_{2} \mathrm{O}_{3}$ ceramic ball with a diameter of $\varnothing 6 \mathrm{~mm}$ was pressed with a known force $(F)$ onto the surface of the rotating sample with the tested layer. As a result of sample rotation at known rotational speed $(v)$, the abrasive wear path is wiped on the sample surface. The abrasion resistance of the tested layer is determined as the wear indicator $\left(W_{z}\right)$ determined by the relationship:

$$
W_{\mathrm{z}}=V /(F \cdot S)
$$

where: $V$ - volumetric wear of the sample material $\left[\mathrm{mm}^{3}\right], F$ - friction node load $[\mathrm{N}], S$ - friction path $[\mathrm{km}]$.

With the assumed operating parameters of the device, the test cycle lasted about $5000 \mathrm{~s}$. Tests were carried out for two temperature values: $25^{\circ} \mathrm{C}$ and $100{ }^{\circ} \mathrm{C}$. After the tests, photos of the wipe path were taken on the surface of the test sample and the wipe trace cross profile was scanned. Three abrasive wear tests were performed for each tested layer. For each of the three resulting wiping paths on the tested samples with layers, the wear index was determined based on the measurements of the wear profile, and then the average value of the wear index for each tested layer.

Corrosion resistance tests of samples with layers were carried out in laboratory conditions, in an atmosphere of salt fog, in the Prohesion chamber. 


\section{Results}

\section{Layer structure}

$\mathrm{X}$-ray phase analysis of the chromed surface of $\mathrm{X} 210 \mathrm{Cr} 12$ tool steel samples showed the presence of chromium carbide type $(\mathrm{Cr}, \mathrm{Fe})_{7} \mathrm{C}_{3}$ and traces of nitride type $(\mathrm{Cr}, \mathrm{Fe})_{2} \mathrm{~N}$.

The microscopic image of the $\mathrm{CrC}$ type carbide layer formed on the surface of tool steel in the process of powder diffusion chromizing $\left(900^{\circ} \mathrm{C}\right.$ for 10 hours), revealed by nital etching of a metallographic cut perpendicular to the sample surface, is shown in fig. 4.

The $\mathrm{CrC}$ type carbide layer, approximately $11 \mu \mathrm{m}$ thick, is separated by a clear boundary from the material base. At the same time, primary (large) and secondary (small) chromium carbides were revealed in the $\mathrm{X} 210 \mathrm{Cr} 12$ tool steel substrate, which is a structural component of this steel.

$\mathrm{Cr}$, Fe and $\mathrm{C}$ concentration distributions in $\mathrm{CrC}$ type carbide layers obtained using an $\mathrm{X}$-ray micro-analyzer are shown in fig. 5.

$\mathrm{Cr}, \mathrm{Fe}$ and $\mathrm{C}$ concentration profiles in carbide layers were characterized by a gradual decrease in the chromium content as the distance from the surface increases: from approximately $60 \%$ in the zone just next to the layer surface to approximately $50 \%$ on the border between the layer and the steel substrate. Decrease in the chromium content in the layer was associated with a simultaneous increase in the iron concentration, while the carbon content remained at a constant level of about $9 \%$, corresponding to the carbon content in the carbide type $(\mathrm{Cr}, \mathrm{Fe})_{7} \mathrm{C}_{3}$ [7]. Thickness of the carbide layer was about $11 \mu \mathrm{m}$, and its hardness - about $1850 \mathrm{HV}$.

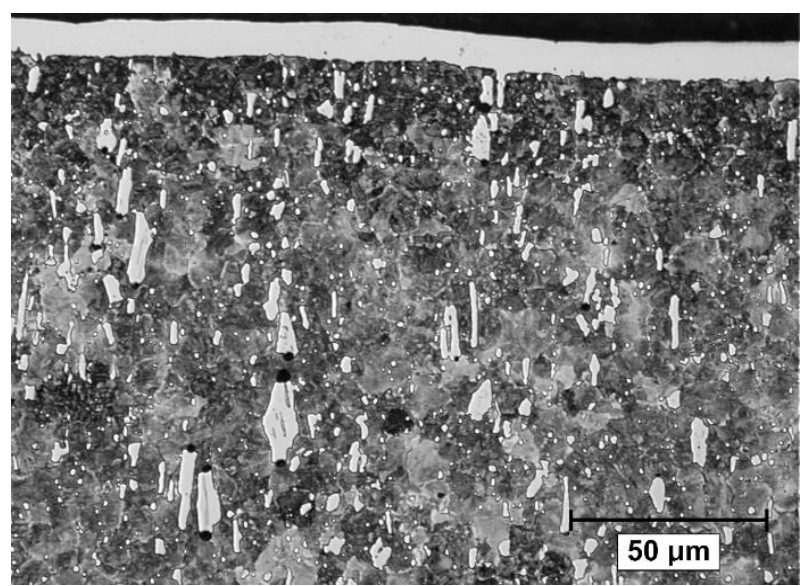

Fig. 4. X210Cr12 steel microstructure with $\mathrm{CrC}$ type carbide layer. Etching with $2 \% \mathrm{HNO}_{3}$

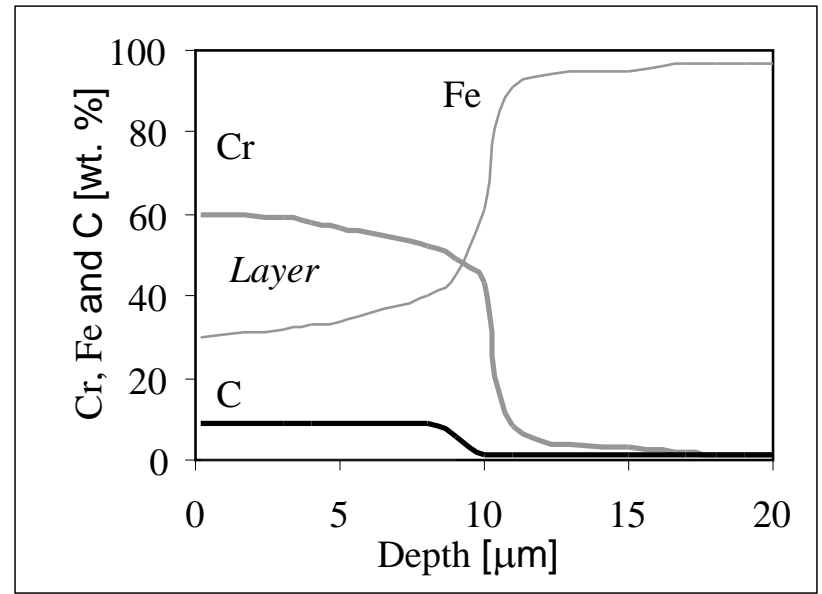

Fig. 5. Concentration depth profile of components in the $\mathrm{CrC}$ type carbide layer

$\mathrm{X}$-ray phase analysis of the surface of $\mathrm{X} 210 \mathrm{Cr} 12$ steel samples with hybrid layers of $\mathrm{CrC}+\mathrm{CrN}$ type showed the presence of chromium carbide type $(\mathrm{Cr}, \mathrm{Fe})_{7} \mathrm{C}_{3}$ and chromium nitride $\mathrm{CrN}$. The microscopic image of the $\mathrm{CrC}+\mathrm{CrN}$ hybrid layer produced on the surface of the tool steel, revealed by nital etching of a metallographic cross-section of the layer, is shown in Fig. 6. 


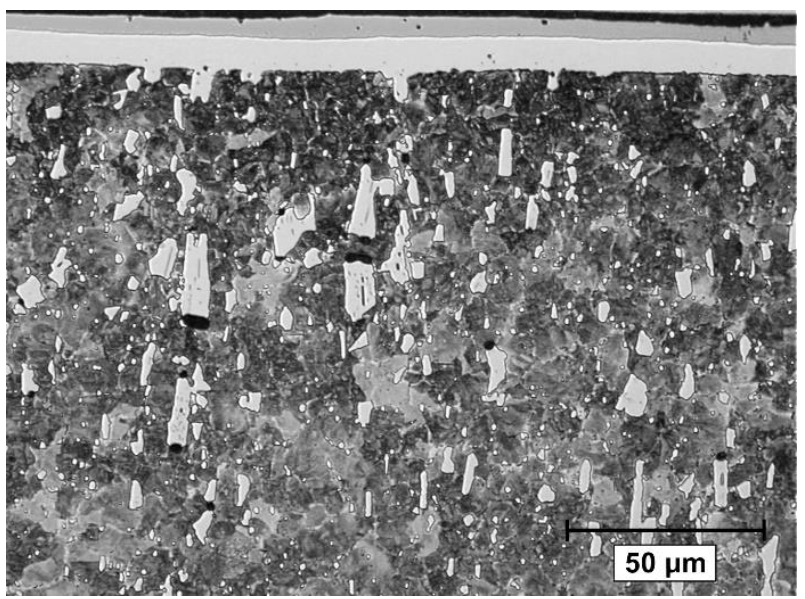

Fig. 6. $\mathrm{X} 210 \mathrm{Cr} 12$ steel microstructure with a $\mathrm{CrC}+\mathrm{CrN}$ hybrid layer. Etching with $2 \% \mathrm{HNO}_{3}$

Observations of the microstructure of the sample with the $\mathrm{CrC}+\mathrm{CrN}$ hybrid layer revealed the presence of two zones: the first zone, from the surface of the layer, about $3 \mu \mathrm{m}$ thick, containing $\mathrm{CrN}$ chromium nitride, and the second zone, about $11 \mu \mathrm{m}$ thick, located between the $\mathrm{CrN}$ coating and a steel substrate containing chromium carbide (fig. 6). This is evidenced by the concentration distribution of the elements $\mathrm{Cr}, \mathrm{Fe}, \mathrm{C}$ and $\mathrm{N}$ in the hybrid layer obtained with the help of X-ray micro-analyzer (fig. 7) and the results of X-ray phase analysis of the sample surface from $\mathrm{X} 210 \mathrm{Cr} 12$ steel with the hybrid layer.

The main components of the first, outer part of the hybrid layer containing $\mathrm{CrN}$ were chromium and nitrogen (fig. 7), which indicated the presence of chromium nitride.

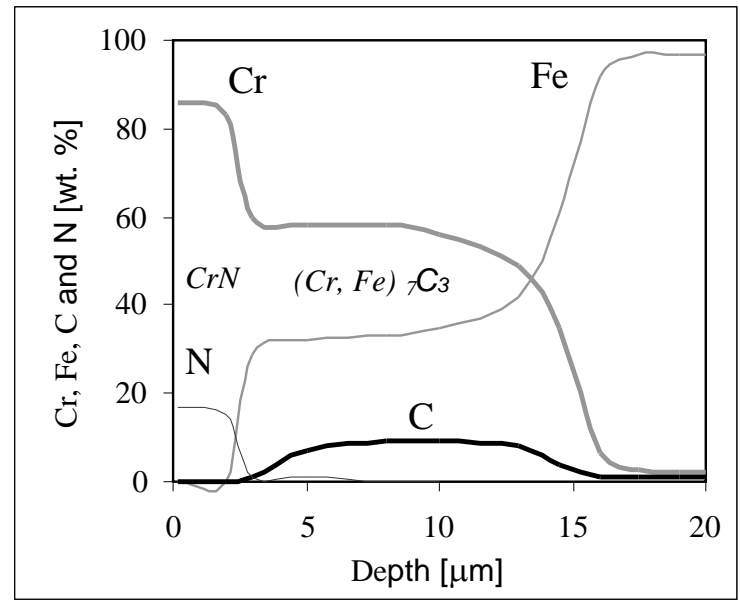

Fig. 7. Concentration depth profile of components in the hybrid layer of $\mathrm{CrC}+\mathrm{CrN}$ type

In the second zone of the hybrid layer, located between the CrN coating and the steel substrate, there was chromium carbide (figs. 6 and 7). This was demonstrated by the content of elements in this zone (approximately $60-50 \% \mathrm{Cr}$, about $9 \% \mathrm{C}$, the rest - $\mathrm{Fe}$ ) and X-ray phase analysis, indicating the presence of carbide type $(\mathrm{Cr}, \mathrm{Fe})_{7} \mathrm{C}_{3}$.

The total thickness of the hybrid layer of $\mathrm{CrC}+\mathrm{CrN}$ was about $15 \mu \mathrm{m}$ and its hardness - about $2200 \mathrm{HV}$.

\section{Tribological properties}

Ball-on-disc wear tests were carried out at an ambient temperature of $25{ }^{\circ} \mathrm{C}$ and $100{ }^{\circ} \mathrm{C}$ for samples from X210Cr12 alloy steel with layers:

- $\mathrm{CrC}$ carbide, produced in the process of diffusion chromizing,

- hybrid $\mathrm{CrC}+\mathrm{CrN}$ type, produced in two processes: diffusion chromizing and deposition of $\mathrm{CrN}$ coating by Arc PVD method.

According to the adopted test methodology, the maximum depth of the wiping path $\left(h_{\max }\right)$, volumetric consumption of sample material $(V)$ and the wear indicator $\left(W_{z}\right)$ were determined during the test.

Wiping paths on the surface of samples with layers (illustrated using a Keyence VHX 1000 digital microscope) and wiping profiles for both types of layers, after tribological tests carried out at $25^{\circ} \mathrm{C}$ and $100{ }^{\circ} \mathrm{C}$, are shown 
in figs. 8-11. The average values of abrasive wear indicators, determined for each layer based on three tests, are given in tab. II.

TABLE II. Indicators of abrasive wear determined for samples from tool steel X210Cr12 with carbide layers of the $\mathrm{CrC}$ type and hybrid layers of the $\mathrm{CrC}+\mathrm{CrN}$ type, determined by the ball-disc method, for temperatures of $25^{\circ} \mathrm{C}$ and $100{ }^{\circ} \mathrm{C}$

\begin{tabular}{|l|c|c|c|}
\hline \multicolumn{1}{|c|}{$\begin{array}{c}\text { Layer type } \\
\text { Carbide } \mathrm{CrC}\end{array}$} & $\begin{array}{c}\text { Temperature } \\
T\left[{ }^{\circ} \mathrm{C}\right]\end{array}$ & $\begin{array}{c}\text { Maximum wiping } \\
\text { depth } \\
h_{\max }[? \mathrm{l} \mathrm{m}]\end{array}$ & $\begin{array}{c}\text { Wear indicator } \\
W_{\mathrm{z}} \\
{\left[\mathrm{mm}^{3} / \mathrm{N} \cdot \mathrm{km}\right]}\end{array}$ \\
\hline \multirow{2}{*}{ Hybrid $\mathrm{CrC}+\mathrm{CrN}$} & 25 & 2.76 & $27.24 \cdot 10^{-3}$ \\
\cline { 2 - 4 } & 100 & 3.72 & $30.14 \cdot 10^{-3}$ \\
\cline { 2 - 4 } & 25 & 2.11 & $11.87 \cdot 10^{-3}$ \\
\hline
\end{tabular}
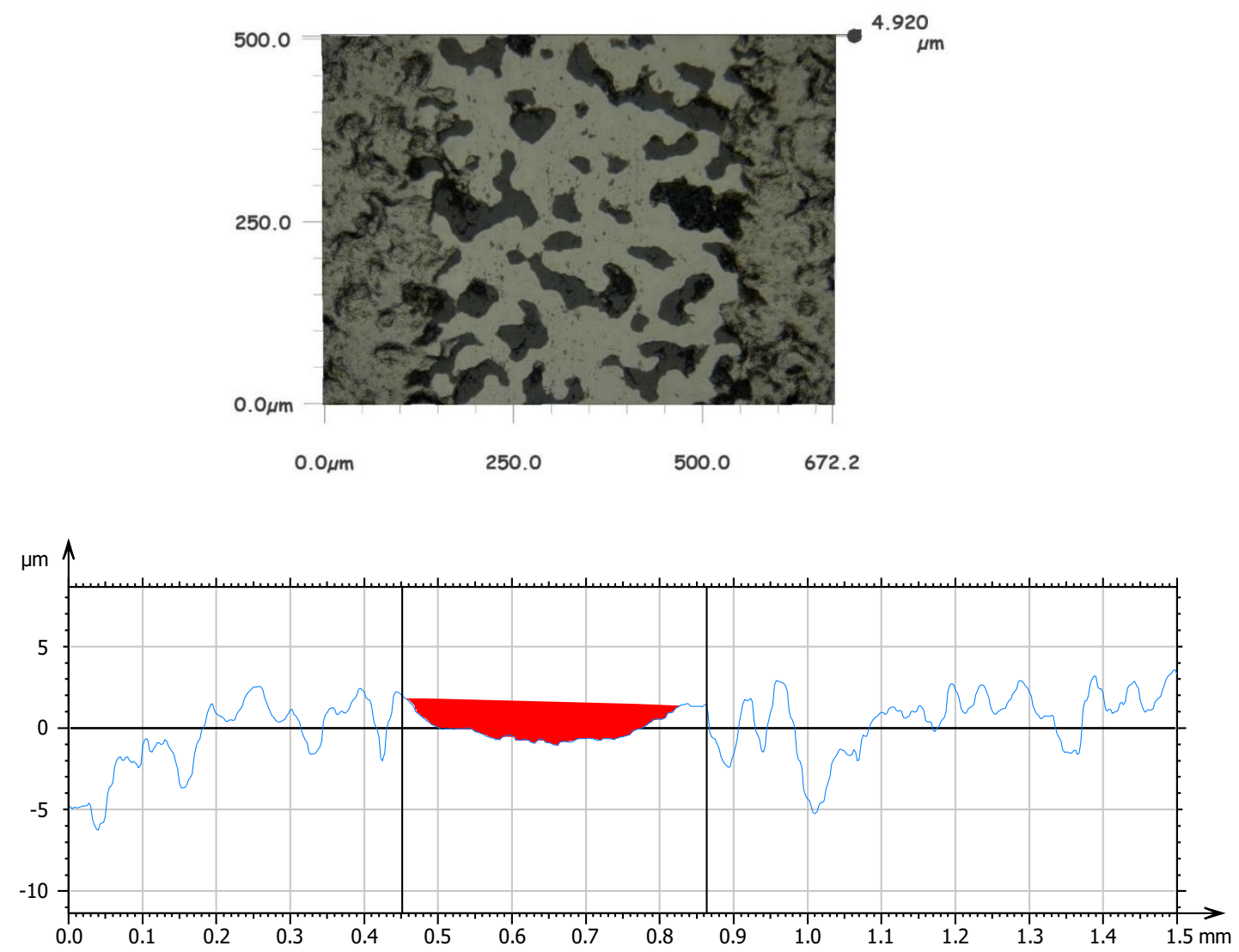

Fig. 8. Wipe path on the surface of a tool steel sample with $\mathrm{CrC}$ type carbide layer and wipe profile after ball-disc test carried out at $25^{\circ} \mathrm{C}$

Maximum wiping depths for samples with $\mathrm{CrC}+\mathrm{CrN}$ hybrid layers were: $h_{\max }=2.11 \mu \mathrm{m}$ at $25^{\circ} \mathrm{C}$ and $h_{\max }=2.55$ $\mu \mathrm{m}$ at $100^{\circ} \mathrm{C}$, respectively, and were therefore smaller than the maximum wiping depths for samples with $\mathrm{CrC}$ type carbide layers, which were respectively: $h_{\max }=2.76 \mu \mathrm{m}$ at $25^{\circ} \mathrm{C}$ and $h_{\max }=3.72 \mu \mathrm{m}$ at $100{ }^{\circ} \mathrm{C}$. This indicates less wear on the hybrid layers. In both cases, the maximum wiping depths of the samples at $25^{\circ} \mathrm{C}$ were smaller than at $100{ }^{\circ} \mathrm{C}$ (tab. II).

The abrasive wear index for samples with $\mathrm{CrC}+\mathrm{CrN}$ hybrid layers at $25^{\circ} \mathrm{C}$ was $W_{z}=11.87 \times 10^{-3} \mathrm{~mm}^{3} / \mathrm{N} \times \mathrm{km}$, thus it was about $40 \%$ lower than the wear index for samples with carbide layers CrC type, which was $W_{z}=$ $27.24 \times 10^{-3} \mathrm{~mm}^{3} / \mathrm{N} \times \mathrm{km}$ (tab. II).

The abrasive wear index for samples with $\mathrm{CrC}+\mathrm{CrN}$ hybrid layers at $100^{\circ} \mathrm{C}$ was $W_{z}=19.41 \times 10^{-3} \mathrm{~mm}^{3} / \mathrm{N} \times \mathrm{km}$, thus it was about $60 \%$ lower than the wear index for samples with carbide layers $\mathrm{CrC}$ type, which was $W_{z}=$ $30.14 \times 10^{-3} \mathrm{~mm}^{3} / \mathrm{N} \times \mathrm{km}$ (tab. II). This indicates less wear on the hybrid layer compared to the carbide layer. 


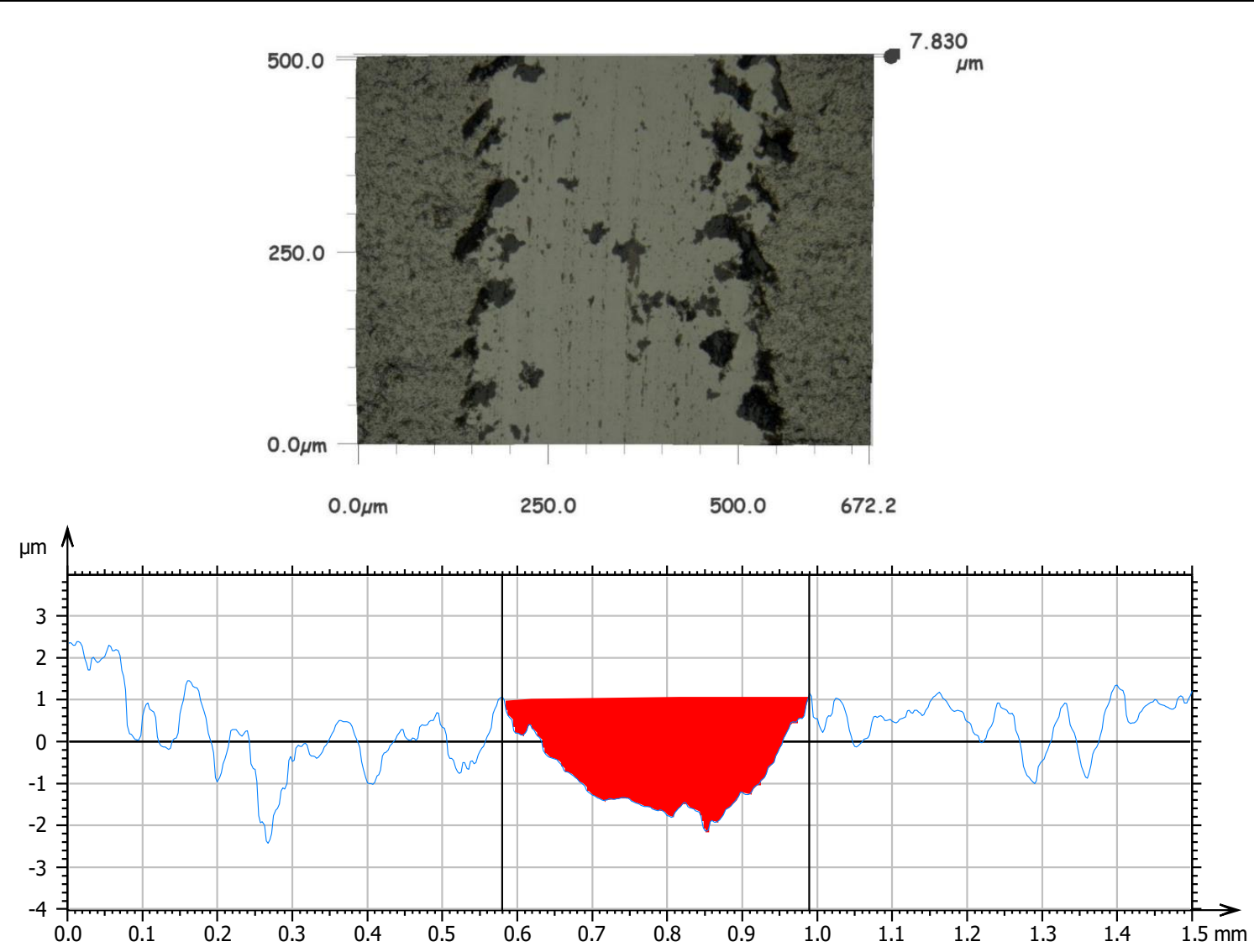

Fig. 9. Wipe path on the surface of tool steel sample with $\mathrm{CrC}$ type carbide layer and a wipe profile after a ball-on-disc test carried out at $100{ }^{\circ} \mathrm{C}$
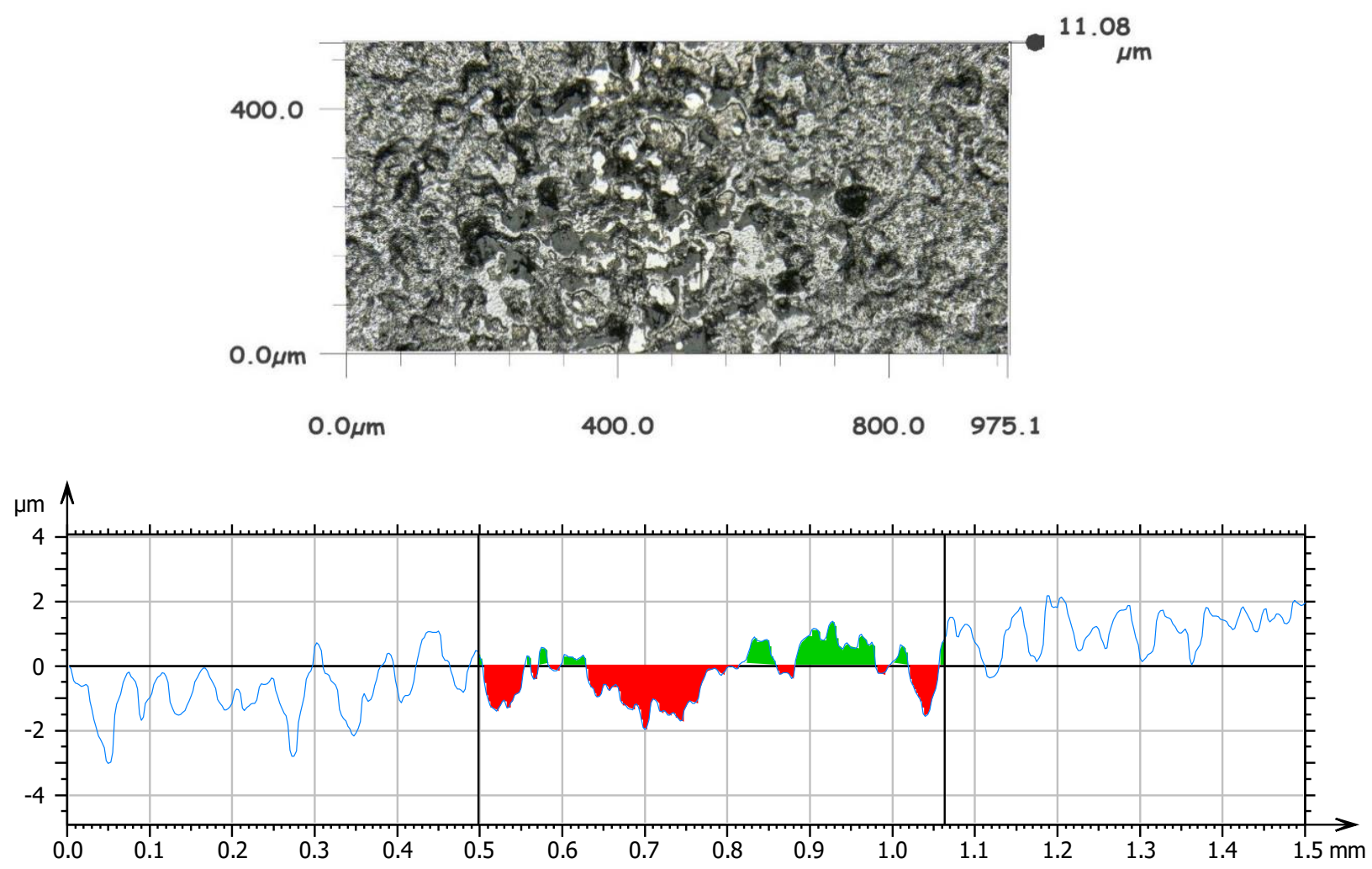

Fig. 10. Wipe path on the surface of tool steel sample with hybrid layer of $\mathrm{CrC}+\mathrm{CrN}$ type and wipe profile after ball-on-disc test carried out at $25^{\circ} \mathrm{C}$ 


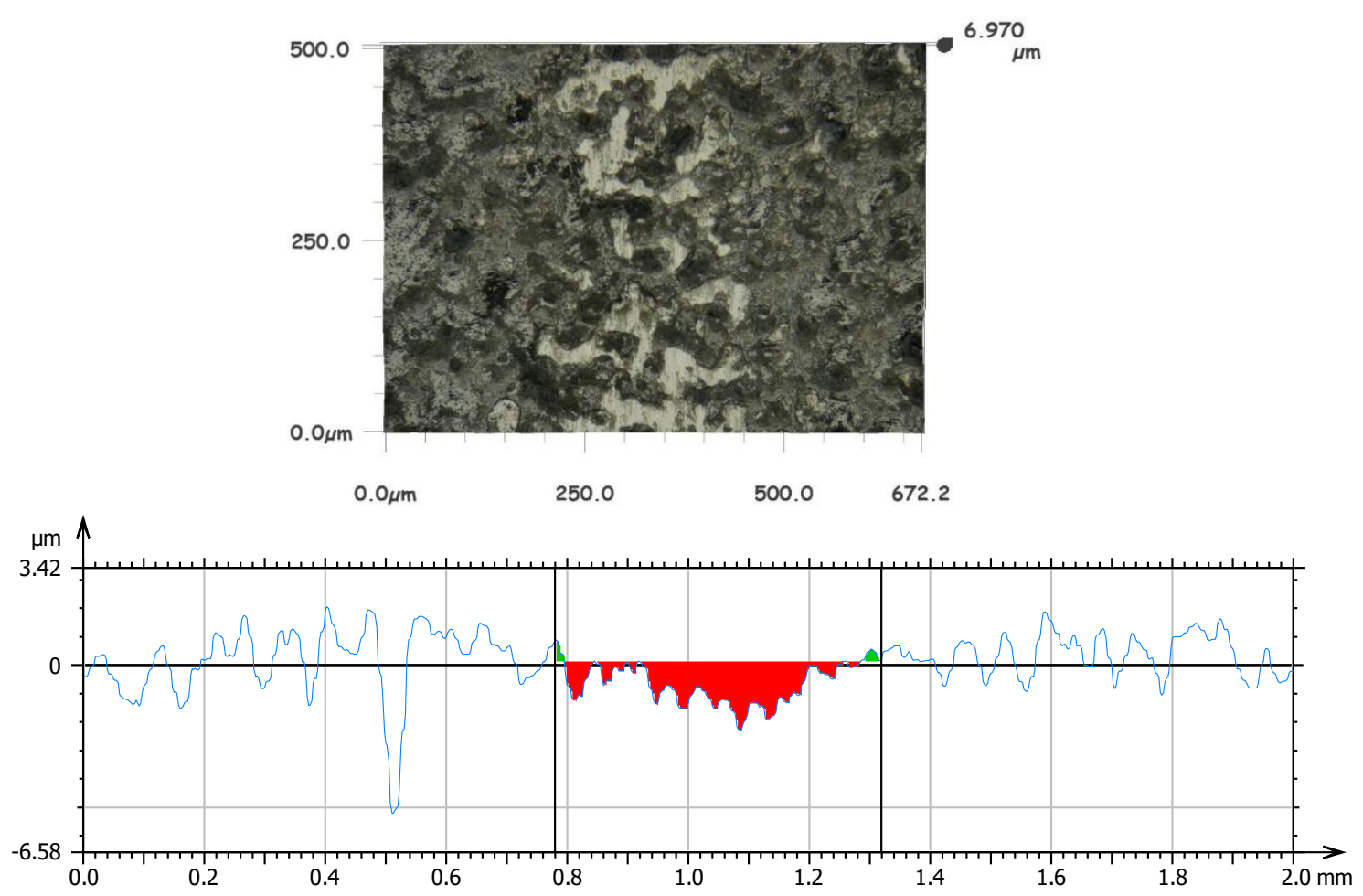

Fig. 11. Wipe path on the surface of tool steel sample with hybrid layer of $\mathrm{CrC}+\mathrm{CrN}$ type and wipe profile after ball-on-disc test carried out at $100{ }^{\circ} \mathrm{C}$

\section{Corrosion resistance of samples}

Corrosion resistance tests of $\mathrm{X} 210 \mathrm{Cr} 12$ steel samples with hybrid layers of $\mathrm{CrC}+\mathrm{CrN}$ type, carbide layers of $\mathrm{CrC}$ type and samples of this steel without layers were carried out in a salt chamber in an atmosphere of salt fog (exposure time: 100 hours). The appearance of samples after corrosion tests is shown in fig. 12.

a)

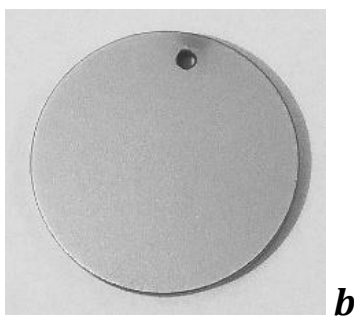

b)

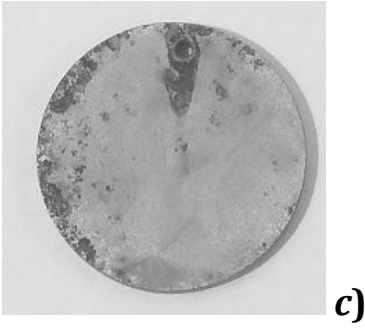

c)

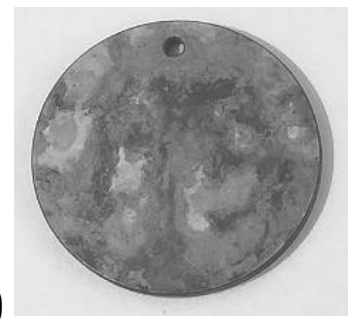

Fig. 12. Samples of $\mathrm{X} 210 \mathrm{Cr} 12$ steel: a) with hybrid layer of $\mathrm{CrC}+\mathrm{CrN}$ type, b) with carbide layer of $\mathrm{CrC}$ type, c) without layer

As it can be seen: samples with hybrid layers of $\mathrm{CrC}+\mathrm{CrN}$ type after 100-hour salt spray exposure showed no surface change, samples with $\mathrm{CrC}$ carbide layers showed signs of corrosion, while samples from uncoated $\mathrm{X} 210 \mathrm{Cr} 12$ steel corroded completely. These results testify to the very good corrosion resistance of $\mathrm{CrC}+\mathrm{CrN}$ hybrid layers in the environment of aggressive media containing chloride ions.

\section{Conclusions and discussion}

The subject of the research was to assess the possibilities of increasing the durability and reliability of tools used in the production of tires in the rubber industry, exposed during operation to tribological wear, corrosion and increased temperature (up to approximately $100^{\circ} \mathrm{C}$ ). The research focused on improving the performance of disc-cutters for cutting the rubber. In order to increase their durability and reliability, hybrid machining of $\mathrm{X} 210 \mathrm{Cr} 12$ tool steel used for the production of disc-cutters as used, consisting in combining a cheaper and technologically simple method of powder diffusion chromizing with Arc PVD treatment, which deposits chromium nitride coatings.

$\mathrm{CrC}+\mathrm{CrN}$ hybrid layers were compared with single $\mathrm{CrC}$ type carbide layers produced on steel in a diffusion chromizing process. 
The diffusion chromizing of $\mathrm{X} 210 \mathrm{Cr} 12$ tool steel using traditional powder method has enabled the production of $(\mathrm{Cr}, \mathrm{Fe})_{7} \mathrm{C}_{3}$ chromium carbide layers containing traces of nitride $(\mathrm{Cr}, \mathrm{Fe})_{2} \mathrm{~N}$, similarly to other known diffusion chromizing methods, in which chromium halides are activators of the process [7-10,18-20]. Thickness of $\mathrm{CrC}$ type carbide layers was about $11 \mu \mathrm{m}$ for chromizing processes carried out during 10 hours. at $900{ }^{\circ} \mathrm{C}$.

The $\mathrm{CrC}+\mathrm{CrN}$ hybrid layers, produced by the Arc PVD deposition of a $\mathrm{CrN}$ chromium nitride coating on the chromium carbide surface, were composed of two zones: the first zone from the surface of the layer contained $\mathrm{CrN}$ chromium nitride, and the second, located between the $\mathrm{CrN}$ coating and the steel substrate, contained chromium carbide type $(\mathrm{Cr}, \mathrm{Fe})_{7} \mathrm{C}_{3}$. Thickness of the hybrid layer was about $15 \mu \mathrm{m}$.

Hardness of the hybrid layer (about $2200 \mathrm{HV}$ ) was about 20\% higher than the carbide layer (about 1840 $\mathrm{HV}$ ), which was probably due to the presence of the hard $\mathrm{CrN}$ phase on its surface.

Ball-on-disc wear tests at ambient temperature of $25{ }^{\circ} \mathrm{C}$ and $100{ }^{\circ} \mathrm{C}$ for samples from X210Cr12 alloy tool steel with hybrid and carbide layers showed that in both cases the maximum wear depths and abrasive wear indicators of the samples with layers at $25^{\circ} \mathrm{C}$ were smaller than at $100^{\circ} \mathrm{C}$, which indicates better tribological properties of these samples at ambient temperature (tab. II).

The wear rates of samples with $\mathrm{CrC}+\mathrm{CrN}$ hybrid layers at $25^{\circ} \mathrm{C}$ and $100{ }^{\circ} \mathrm{C}$ were about $40 \%$ and $60 \%$ lower, respectively, than the wear rates for samples with $\mathrm{CrC}$-type carbide layers (tab. II). Test results show very good tribological properties of hybrid layers both at $25^{\circ} \mathrm{C}$ and $100{ }^{\circ} \mathrm{C}$, as opposed to carbide layers, where the abrasive wear was much higher.

Also, the corrosion resistance of samples with hybrid layers, assessed by means of salt spray tests, proved significantly better than samples with carbide layers.

Hence, $\mathrm{CrC}+\mathrm{CrN}$ hybrid coatings can be used to improve the performance of steel tools exposed to frictional wear, temperatures raised to approximately $100^{\circ} \mathrm{C}$ and corrosion in aggressive environments containing chloride ions.

\section{REFERENCES}

[1] Bogdański B., Więczkowski A., Kasprzycka E., Kołodziejska K. „Zastosowanie chromowania dyfuzyjnego dla zwiększania trwałości narzędzi narażonych na zużycie tribologiczne". Problemy techniki. P. Grabowski, A. Krawczyńska-Piechna, J. Wernik (red.). Płock: Politechnika Warszawska, Wydział Budownictwa Mechaniki i Petrochemii, 2017, 182-191.

[2] Więczkowski A. „Zwiększenie trwałości wybranych narzędzi stosowanych w przemyśle gumowym”. Rozprawa doktorska (promotor: E.Kasprzycka). Warszawa: Oficyna Wydawnicza Politechniki Warszawskiej, 2018.

[3] Mazurkiewicz A., Smolik J. „The innovative direction of hybrid technologies development and implementations in surface engineering area". Archives of Metallurgy and Materials. 57, 3 (2012): 657-664.

[4] Smolik J. „Hybrydowe technologie inżynierii powierzchni”. Radom: Wydawnictwo ITeE-PIB, 2016.

[5] Mazurkiewicz A., Smolik J. „Zaawansowane technologie inżynierii powierzchni wspomagające procesy eksploatacji i wytwarzania". Radom: Wydawnictwo ITeE-PIB, 2015.

[6] Kasprzycka E. „Properties of tool steel with $\mathrm{Cr} / \mathrm{CrN}$ type hybrid coatings, obtained by PVD method". Archives of Metallurgy and Materials. 64, 1 (2019): 293-301.

[7] Kasprzycka E. “Chromizing”. Encyclopedia of Tribology. Q.J. Wang,Y.-W. Chung (red.). New York: SpringerVerlag Editors, 2013.

[8] Lee J.W., Duh J.G. „Evaluation of microstructures and mechanical properties of chromized steels with different carbon contents". Surface and Coatings Technology. 177-178 (2004): 525-531.

[9] Lee J.W., Wang H.C., Li J.L., Lin C.C. „Tribological properties evaluation of AISI 1095 steel chromized at different temperatures". Surface and Coatings Technology. 188-189 (2004): 550-555.

[10] Bai C.Y., Luo Y.J., Koo C.H. „Improvement of high temperature oxidation and corrosion resistance of superalloy IN-738LC by pack cementation". Surface and Coatings Technology. 183, 1 (2004):74-88.

[11] Wang Z.B., Lu J., LuK. „Chromizing behaviors of a low carbon steel processed by means of surface mechanical attrition treatment". Acta Materialia. 53, 7 (2005): 2081-2089.

[12] Huiling C., Luo C.P., Jangwen L., Ganfeng Z. „Phase transformations in low-temperature chromized 0,45 wt\%C plain carbon steel".Surface and Coatings Technology. 201 (2007): 7970-7977.

[13] Kacprzyńska-Gołacka J., Mazurkiewicz A., Smolik J. „Analysis of resistance to cracking of multicomponent coatings based on chromium nitride". Inżynieria Materialowa. 3 (2014): 1-3.

[14] Bayon R., Nevshupa R., Zubizarreta C., Ruiz de Gopegui U., Barriga J.,Igartua A. „Characterisation of tribocorrosion behaviour of multilayer PVD coatings". Analytical and Bioanalytical Chemistry. 396 (2010):28552862.

[15] Song G.-H., Yang X.-P., Xiong G.-L., Lou Z., Chen L.-J. „The corrosive behavior of Cr/CrN multilayer coatings with different modulation periods". Vacuum. 89 (2013): 136-141. 
[16] Wołczyński W. „Large Steel Ingots: Microstructure Mathematical Modeling”. Encyclopedia of Iron, Steel and Their Alloys, Five-Volume Set. Rafael Colás and George Totten (red.). Nowy Jork: Taylor\& Francis Group, Inc. 2016.

[17] Wołczyński W. „Back-diffusion in crystal growth. Eutectics”. Archives of Metallurgy and Materials. 60 (2015): 2403-2407.

[18] Bogdański B., Kasprzycka E. „Tribological characterizations of chromized carbide layers produced by the pack powder method at low pressure". Tribologia. 3 (2015): 9-19.

[19] Kasprzycka E., Bogdański B., Senatorski J., Gębski P., Więczkowski A.,Tribological properties of the hybrid layers produced in chromizing process by pack powder method and PVD treatment". Tribologia. 2(2014): 7988.

[20] Kasprzycka E., Bogdański B. „Properties of tool steel after hybrid treatment connecting diffusion chromizing with the PVD method".Archives of Metallurgy and Materials. 64, 1 (2019): 235-242. 